\title{
LATS2 wt Allele
}

National Cancer Institute

\section{Source}

National Cancer Institute. LATS2 wt Allele. NCI Thesaurus. Code C51211.

Human LATS2 wild-type allele is located within 13q11-q12 and is approximately $87 \mathrm{~kb}$ in length. This allele, which encodes serine/threonine-protein kinase LATS2 protein, is involved in centrosome duplication and the maintenance of mitotic fidelity. Downregulation of LATS1 gene expression by promoter hypermethylation is associated with an agg ressive phenotype in breast cancer. 